\title{
Pengaruh Diameter Ahukle'an dan Takaran Kompos Biochar terhadap Pertumbuhan dan Hasil Tanaman Jagung (Zea mays L.) Lokal Putih di Lahan Kering
}

\author{
Maria Adisandri Aek ${ }^{\mathrm{a}}$, \\ ${ }^{a}$ Fakultas Pertanian, Universitas Timor, Kefamenanu, TTU-NTT, Indonesia, email: adisandriaek@gmail.com
}

\section{Article Info}

Article history:

Received 23 Desember 2019

Received in revised form 13 Mare 2019

Accepted 18 April 2020

DOI:

https://doi.org/10.32938/sc.v5i02.937

\section{Keywords:}

Diameter Ahukle'an

Kompos Biochar

Zea mays $L$

\begin{abstract}
Abstrak
Jagung adalah salah satu bahan pangan utama selain padi bagi masyarakat di pulau Timor. Karena itu masyarakat di pulau ini me miliki cara penanaman jagung yang berbeda dari masyarakat di pulau-pulau lain di Indonesia. Salah satu teknik budidaya masyarakat yang ada dan merupakan kearifan lokal masyarakat adalah Ahukle'an, yang merupakan teknik budidaya jagung yang dikembangkan oleh masyarakat di kawasan Besikama, Kabupaten Malaka, Kecamatan Malaka Barat, Nusa Tenggara Timur (NTT). Penelitian ini bertujuan untuk mengetahui pertumbuhan dan hasil varietas jagung lokal dalam sistem Ahukle'an dan aplikasi biochar di lahan kering yang dilaksanakan pada bulan Mei-September 2019 di kebun percobaan Fakultas Pertanian Universitas Timor, Kabupaten Timor Tengah Utara, Kecamatan Kota Kefamenanu. Penelitian ini menggunakan Rancangan Petak Beralur (Strip Plot Design) pada faktorial terdiri dari 2 faktor. Faktor pertama yakni Diameter ahukle'an terdiri dari 2 level yakni $7,5 \mathrm{~cm}, 15 \mathrm{~cm}$. Faktor kedua yakni takaran kompos biochar yang terdiri dari 3 level yakni tanpa kompos biochar, kompos biochar $5 \mathrm{t} / \mathrm{Ha}$, kompos biochar $10 \mathrm{t} / \mathrm{Ha}$. Hasil penelitian menunjukan bahwa Terjadi interaksi antar perlakuan kompos biochar dan diameter ahukle'an terhadap parameter pengamatan suhu tanah 28 HST, 35 HST, 42 HST, 56 HST, dan 63 HST; jumlah daun 42 HST, 49 HST, dan 63 HST. Terjadi interaksi antar perlakuan kompos biochar dan diameter ahukle'an terhadap parameter pengamatan suhu tanah 28 HST, 35 HST, 42 HST, 56 HST, dan 63 HST; jumlah daun 42 HST, 49 HST, dan 63 HST. Perlakuan diameter ahukle'an $15 \mathrm{~cm}$ berpengaruh terhadap hasil berat pipilan kering per tanaman $(44,68 \mathrm{~g})$. Takaran kompos biochar $5 \mathrm{t} / \mathrm{Ha}$ berpengaruh nyata terhadap hasil berat pipilan kering per tanaman $(31,81 \mathrm{~g})$.
\end{abstract}

\section{Pendahuluan}

Jagung adalah salah satu bahan pangan utama selain Padi bagi masyarakat di pulau Timor. Karena itu masyarakat di pulau ini memiliki cara penanaman Jagung yang berbeda dari masyarkat di pulau-pulau lain di Indonesia. Salah satu teknik budidaya masyarakat yang ada dan merupakan kearifan lokal masyarakat adalah Ahukle'an, yang merupakan teknik budidaya jagung yang dikembangkan oleh masyarakat di kawasan Besikama, Kabupaten Malaka, Kecamatan Malaka Barat, Nusa Tenggara Timur (NTT). Penanaman jagung dengan cara Ahukle'an biasanya dilakukan pada musim kemarau antara bulan Juli-Oktober, dengan memanfaatkan kelembaban tanah yang masih ada di lapisan bawah dengan cara membuat lubang tanam lebih dalam dibandingkan dengan tanam jagung yang biasa.

Sistem usaha tani Jagung Ahukle'an merupakan suatu upaya pemanfaatan lahan endapan dan resapan air sungai pada musim kemarau (bulan Juli-Oktober) dengan menanam jagung yang ditugal secara dalam tanpa mendapat pengairan tambahan baik hujan maupun irigasi. Pada sistem ini masyarakat menanam jagung dengan membuat lubang tanam yang dalam antara $25-30 \mathrm{~cm}$. Sistem usahatani ini hanya dilaksanakan pada musim kemarau. Jagung tumbuh dan berkembang tanpa mendapat pengairan tambahan dan hanya tergantung pada resapan air dari sungai. Usahatani jagung Ahukle'an ini dikembangkan pada musim tanam ketiga dari pola tanam setahun (Leki Seran et al., 2002). Lebih lanjut Leki Seran et al., (2002) menyatakan bahwa pada daerah aliran sungai Benanai yang memiliki ketersediaan air tanah yang cukup dangkal atau daerah yang masih memiliki kelembaban yang cukup untuk diusahakan tanaman jagung maka pada musim ketiga masyarakat melakukan atau mengembangkan sistem usahatani jagung musim ke tiga yang dikenal sistem budidaya jagung Ahukle'an. Pola ini merupakan suatu budaya pertanian yang selalu dilakukan setiap tahun secara rutin. Menurut Wariso (2000) teknologi ini merupakan budaya warisan sehingga penanaman jagung pada musim tanam ke tiga merupakan suatu budaya pertanian dimana petani melakukan penanaman jagung dengan cara ditugal dalam. Sistem usahatani jagung Ahukle'an juga merupakan salah satu budaya pertanian yang dikembangkan oleh masyarakat di daerah aliran sungai (DAS) Benanai.

Masyarakat di daerah dataran sedang sampai dataran tinggi di pulau Timor biasanya menanam jagung hanya satu kali, yaitu pada awal musim hujan (November-Desember) setiap tahun. Budidaya jagung Ahukle'an belum diterapkan masyarakat di lahan kering dataran tinggi, walaupun pada akhir musim hujan (Juni - Agustus) lengas tanah di lapisan bawah masih cukup banyak. Oleh karena itu perlu dicoba untuk mengetahui apakah lubang tanam dengan Ahukle'an di lahan kering harus lebih dalam atau lebih dangkal dari kebiasaan di daerah dataran rendah Malaka. Selain itu, mengingat di lahan kering intensitas cahaya dan temperaturnya tinggi, maka diperlukan masukan teknologi yang tepat untuk mengantisipasi kehilangan lengas oleh evaporasi lebih tinggi. Salah satu teknologi yang dapat digunakan adalah biochar yang sudah terbukti dalam beberapa penelitian mampu memperbaiki kondisi tanah termasuk lengas tanah dan meningkatkan pertumbuhan serta produksi tanaman. Lengas tanah disebut juga sebagai kelembaban tanah. Lengas tanah merupakan kandungan air yang mengisi sebagian atau seluruh pori-pori tanah yang terdapat diatas permukaan tanah.Chan et al., (2007) berpendapat bahwa penggunaan biochar untuk mengikat karbon yang merupakan salah satu cara untuk memerangi perubahan iklim hanya dapat terlaksana secara ekonomis bila $\mathrm{C}$ yang diikat mempunyai nilai-nilai manfaat pembenah tanah dan pemupukan. Untuk kemampuan mempertahankan kelembaban dapat membantu tanaman pada lahan dari kekeringan. Biochar sangat penting dalam memperkaya karbon organik pada tanah marginal dan mempercepat perkembangan mikroba serta mampu meyerap hara dalam tanah. Ini memungkinkan karena struktur berpori dan luas permukaan yang tinggi mengakibatkan nutrisi, fosfor dan bahan kimia pertanian dipertahankan untuk kepentingan tanaman.

Penanaman dengan ahukle'an telah diteliti berbagai pihak dan hasilnya masih termasuk rendah. Hasil penelitian Leki Seran et al., (2002) produktivitas jagung yang dihasilkan dengan menggunakan varietas lokal hanya rata-rata sebanyak 2,08 t/ha dengan kisaran antara 1,88-2,38 t/ha. Rendahnya produksi jagung Ahukle'an disebabkan penggunaan varietas lokal yang potensi produksinya rendah, petani tidak biasa melakukan pemupukan, serta jarak tanam yang lebar yakni 1 x $1 \mathrm{~m}$ (Murdolelono et al., 1999). Di sisi lain, ada kemungkinan disebabkan pula oleh rendahnya kandungan lengas tanah pada musim tanam antara Juli-Oktober. Persoalan-persoalan di atas, terutama yang berhubungan dengan kondisi tanah dapat juga diatasi dengan menggunakan biochar.

Berdasarkan penelitian Nurida et al., (2012), pemberian formula pembenah tanah biochar dengan dosis 5 dan 10 t/ha mampu meningkatkan kandungan $\mathrm{P}$ tersedia dan $\mathrm{K}$ total tanah. Pemberian dosis dengan 2,5 ton/ha belum mampu meningkatkan kandungan $\mathrm{P}$ tersedia dan $\mathrm{K}$ total. Rendahnya kandungan $\mathrm{P}_{2} \mathrm{O}_{5}$ dan $\mathrm{K}_{2} \mathrm{O}$ dalam formula pembenah tanah biochar yaitu hanya 0,90-1,14 \% menyebabkan pemberian dengan dosis rendah tidak mampu meningkatkan kandungan $\mathrm{P}$ dan $\mathrm{K}$ dalam tanah. Setelah satu musim tanam KTK tanah masih tergolong rendah, namum terlihat bahwa pemberian tanah biochar telah mampu meningkatkan KTK tanah secara signifikan. Disimpulkan bahwa formulasi biochar dapat berperan sebagai suatu pembenah tanah yang memacu pertumbuhan tanaman dengan mensuplai dan menahan hara, disamping itu peran lainnya dapat memperbaiki sifat-sifat fisika dan biologi tanah. Berbagai macam penelitian yang telah dilakukan menunjukkan bahwa biochar bermanfaat untuk memperbaiki kualitas secara fisik dengan meningkatkan kapasitas menahan air dan kemantapan agregat, memperbaiki berat isi dan menurunkan ketahanan tanah karena strukturnya yang berpori (Melo et al., 2013).

Penelitian teknik budidaya jagung dengan Ahukle'an menggunakan jagung varietas lokal dan biochar (pembenah tanah) masih perlu dilakukan Biochar yang ditambahkan ke dalam tanah dimaksudkan untuk meningkatkan fungsi tanah menyimpan air bagi kebutuhan tanaman. Biochar merupakan bahan pembenah tanah yang diinginkan di banyak tempat atau lokasi karena memiliki kemampuan untuk mengikat dan menyimpan air serta mencegah terjadinya kehilangan hara akibat aliran permukaan (run off) dan pencucian (leaching). Dari uraian diatas maka penelitian ini bertujuan untuk mengetahui pertumbuhan dan hasil varietas jagung lokal dalam sistem Ahukle'an dan aplikasi biochar di lahan kering.

\section{Metode}

Penelitian ini dilakukan pada bulan Mei-September 2019 di kebun percobaan Fakultas Pertanian Universitas Timor, Kabupaten Timor Tengah Utara, Kecamatan Kota Kefamenanu. Rancangan penelitian yang disusun menggunakan Rancangan Petak Beralur (Strip Plot Design) 3 x 6 yang diulang tiga kali. Dengan 2 faktor perlakuan, Faktor pertama adalah Diameter ahukle'an (D), terdiri dari 2 (dua) level, yaitu: $\mathrm{D}_{1}$ : Diameter 7,5 cm, $\mathrm{D}_{2}$ Diameter $15 \mathrm{~cm}$. Faktor kedua adalah takaran kompos biochar (B) yang terdiri dari 3 (tiga) level, yaitu: $\mathrm{B}_{\mathrm{O}}$ : tanpa kompos biochar 0 t/Ha, $\mathrm{B}_{1}: 5$ t/ $/ \mathrm{Ha}, \mathrm{B}_{2}: 10$ t/Ha. Dengan kombinasi perlakuannya : $B_{0} D_{1}, B_{0} D_{2}, B_{1} D_{1}, B_{1} D_{2}, B_{2} D_{1}, B_{2} D_{2}$, masing-masing diulang tiga kali sehingga terdapat 18 unit percobaan. Sebelum penanaman dengan teknik Ahukle'an, biji jagung direndam dengan air terlebih dahulu selama 2 malam untuk membantu proses perkecambahan. Benih yang 
ditanam pada lubang sebanyak 4 biji per lubang tanam. Jarak tanam yang digunakan dalam penelitian ini adalah $70 \mathrm{~cm}$ x $30 \mathrm{~cm}$. Setelah benih tumbuh dilakukan penjarangan menyisakan 2 tanaman per lubang tanam. Benih yang digunakan dalam penelitian ini adalah benih jagung (zea mays $L$.) varietas lokal putih. Benih diambil dari Desa Rabasa, Kabupaten Malaka, Kecamatan Malaka Barat. Benih jagung yang dipilih berupa benih yang baik, biji yang besar, putih mengkilat, bagian kepalanya tidak pecah atau rusak. Jumlah benih yang digunakan adalah 720 butir benih. Parameter pengamatan dalam penelitian ini berupa: suhu tanah, kadar lengas tanah, tinggi tanaman, jumlah daun, luas daun, berat pipilan kering per tanaman, berat kering berangkasan, indeks panen. Data hasil pengamatan dianalisis menggunakan sidik ragam (Anova) Rancangan petak beralur (Strip Plot Design). Rata-rata perlakuan selanjutnya diuji lanjut dengan menggunakan Duncan Multiple Range Test (DMRT) dengan tingkat signifikasi $5 \%$ sesuai petunjuk Gomez dan Gomez, (1995). Perhitungan aanalisis data penelitian menggunakan alat analisis SAS 9.1.

\section{Hasil dan Pembahasan \\ 3.1 Hasil \\ Suhu Tanah}

Hasil sidikragam (anova) menunjukkan tidak terjadi interaksi antar perlakuan takaran kompos biochar dan diameter ahukle'an terhadap suhu tanah pada pengamatan -1 HST (awal), 21 HST dan 49 HST. Sedangkan pada waktu pengamatan lainnya terjadi interaksi pada pengamatan 28 HST, 35 HST, 42 HST, 56 HST dan 63 HST. Kombinasi perlakuan diameter lubang ahukle'an $7,5 \mathrm{~cm}$ dengan takaran kompos $10 \mathrm{t} / \mathrm{ha}$ menghasilkan suhu tanah terendah dan berbeda nyata dengan kombinasi lainnya (Tabel 1).

Tabel 1. Suhu Tanah $\left({ }^{\circ} \mathrm{C}\right.$

\begin{tabular}{|c|c|c|c|c|}
\hline \multirow{2}{*}{$\begin{array}{c}\text { Waktu } \\
\text { Pengamatan } \\
\text { (HST) }\end{array}$} & \multirow{2}{*}{$\begin{array}{c}\text { TakaranKompos } \\
\text { Biochar (t/Ha) }\end{array}$} & \multicolumn{2}{|c|}{$\begin{array}{l}\text { Diameter Lubang } \\
\text { ahukle'an }(\mathrm{cm})\end{array}$} & \multirow[t]{2}{*}{ Rerata } \\
\hline & & 7,5 & 15 & \\
\hline \multirow{4}{*}{-1} & Kontrol & 24,22 & 23,89 & $24,05 \mathrm{a}$ \\
\hline & 5 & 23,78 & 24,44 & $24,11 \mathrm{a}$ \\
\hline & 10 & 24,66 & 24,11 & $24,39 \mathrm{a}$ \\
\hline & Rerata & $24,22 \mathrm{a}$ & $24,15 \mathrm{a}$ & $(-)$ \\
\hline \multirow{4}{*}{21} & Kontrol & 23,11 & 23,55 & $23,33 \mathrm{a}$ \\
\hline & 5 & 23,00 & 24,11 & $23,55 a$ \\
\hline & 10 & 22,78 & 23,66 & $23,22 \mathrm{a}$ \\
\hline & Rerata & $22,96 b$ & $23,77 \mathrm{a}$ & $(-)$ \\
\hline \multirow{4}{*}{28} & Kontrol & $24,88 \mathrm{a}$ & $25,22 \mathrm{a}$ & 25,05 \\
\hline & 5 & $25,11 \mathrm{a}$ & $25,11 \mathrm{a}$ & 25,11 \\
\hline & 10 & $22,29 \mathrm{~b}$ & $25,11 \mathrm{a}$ & 23,70 \\
\hline & Rerata & 24,09 & 25,15 & $(+)$ \\
\hline \multirow{4}{*}{35} & Kontrol & $23,55 a$ & $23,55 a$ & 23,55 \\
\hline & 5 & $23,11 \mathrm{a}$ & $23,66 a$ & 23,39 \\
\hline & 10 & $20,83 b$ & $23,77 \mathrm{a}$ & 22,30 \\
\hline & Rerata & 22,50 & 23,66 & $(+)$ \\
\hline \multirow{4}{*}{42} & Kontrol & $22,78 \mathrm{a}$ & $22,78 \mathrm{a}$ & 22,78 \\
\hline & 5 & $22,66 a$ & $23,18 \mathrm{a}$ & 22,92 \\
\hline & 10 & $20,94 b$ & $22,44 \mathrm{a}$ & 21,69 \\
\hline & Rerata & 22,13 & 22,80 & $(+)$ \\
\hline \multirow{4}{*}{49} & Kontrol & 23,66 & 23,33 & $23,50 \mathrm{ab}$ \\
\hline & 5 & 23,33 & 22,89 & $23,11 \mathrm{a}$ \\
\hline & 10 & 20,60 & 22,89 & $21,74 b$ \\
\hline & Rerata & $22,53 \mathrm{a}$ & $23,03 \mathrm{a}$ & $(-)$ \\
\hline \multirow{4}{*}{52} & Kontrol & $23,44 a$ & $23,11 \mathrm{a}$ & 23,27 \\
\hline & 5 & $23,11 \mathrm{a}$ & $22,88 \mathrm{a}$ & 23,00 \\
\hline & 10 & $20,59 \mathrm{~b}$ & $22,88 \mathrm{a}$ & 21,92 \\
\hline & Rerata & 22,50 & 22,96 & $(+)$ \\
\hline \multirow{4}{*}{63} & Kontrol & $24,11 \mathrm{a}$ & $23,66 a$ & 23,89 \\
\hline & 5 & $23,88 \mathrm{a}$ & $23,55 \mathrm{a}$ & 23,72 \\
\hline & 10 & $21,95 \mathrm{~b}$ & $23,55 \mathrm{a}$ & 22,70 \\
\hline & Rerata & 23,28 & 23,59 & $(+)$ \\
\hline
\end{tabular}

Keterangan: Angka pada baris dan kolom diikuti huruf yang sama menunjukan beda pada tingkat nyata $(\alpha) 5 \%$ menurut uji DMRT, (-) tidak terjadi interaksi antar faktor, (+) terjadi interaksi antar faktor.

\section{Kadar Lengas Tanah}

Hasil sidik ragam (Anova) menunjukkan tidak terjadi interaksi antar perlakuan takaran kompos biocha rdan diameter ahukle'an terhadap kadar lengas tanah. Aras perlakuan takaran kompos biochar dengan diameter ahukle'an menunjukkan tidak berbeda nyata terhadap kadar lengas tanah, walaupun pada takaran kompos biochar $10 \mathrm{t} / \mathrm{Ha}$ dan diameter ahukle an 7,5 cm menghasilkan kadar lengas tanah tertinggi (Tabel 2)

\section{Tinggi Tanaman}

Hasil sidik ragam (Anova) menunjukan tidak terjadi interaksi anta perlakuan takaran kompos biochar dan diameter ahukle'an terhadap tinggi tanaman pada waktu pengamatan 21 HST sampai dengan 63 HST. Namun pada pengamatan 21 dan 28 HST takaran kompos biochar 5 t/Ha menunjukkan berbeda nyata dengan $10 \mathrm{t} / \mathrm{Ha}$ terhadap tinggi tanaman pada waktu pengamatan. Sedangkan pada pengamatan 42, 49, 56, dan 63 HST diameter ahukle'an $15 \mathrm{~cm}$ berbeda nyata dengan diameter ahukle'an 7,5 $\mathrm{cm}$. Perlakuan takaran kompos biochar $10 \mathrm{t} / \mathrm{Ha}$ dan diameter ahukle'an $15 \mathrm{~cm}$ cenderung meningkatkan tinggi tanaman paling tinggi. Meningkatnya tinggi tanaman dipengaruhi oleh kualitas kompos biochar dan diameter ahukle'an dibandingkan dengan perlakuan lainnya (Tabel 3)

Tabel 2. Kadar Lengas Tanah $(\%)$

\begin{tabular}{cccc}
\hline Takaran Kompos & \multicolumn{2}{c}{ Diameter ahukle'an $(\mathrm{cm})$} & \multirow{2}{*}{ Rerata } \\
\cline { 2 - 3 } Biochar $(\mathrm{t} / \mathrm{Ha})$ & 7,5 & 15 & \\
\hline Kontrol & 29,33 & 23,41 & $26,37 \mathrm{a}$ \\
5 & 26,49 & 21,24 & $23,87 \mathrm{a}$ \\
10 & 24,34 & 33,23 & $28,79 \mathrm{a}$ \\
\hline Rerata & $26,72 \mathrm{a}$ & $25,96 \mathrm{a}$ & $(-)$ \\
\hline
\end{tabular}

Keterangan:Angka pada baris dan kolom diikuti huruf yang sama menunjukan beda pada tingkat nyata $(\alpha)=5 \%$ menurut uji DMRT (-) tidak terjadi interaksi antar faktor.

Tabel 3. Tinggi Tanaman $(\mathrm{cm})$

\begin{tabular}{|c|c|c|c|c|}
\hline \multirow{2}{*}{$\begin{array}{c}\text { Waktu } \\
\text { Pengamatan } \\
\text { (HST) }\end{array}$} & \multirow{2}{*}{$\begin{array}{c}\text { Takaran Kompos } \\
\text { Biochar (t/Ha) }\end{array}$} & \multicolumn{2}{|c|}{ Diameter ahukle 'an $(\mathrm{cm})$} & \multirow{2}{*}{ Rerata } \\
\hline & & 7,5 & 15 & \\
\hline \multirow{4}{*}{21} & Kontrol & 44,54 & 47,22 & $45,88 \mathrm{ab}$ \\
\hline & 5 & 45,55 & 54,05 & $49,80 \mathrm{a}$ \\
\hline & 10 & 39,82 & 41,31 & $40,57 \mathrm{~b}$ \\
\hline & Rerata & $43,31 \mathrm{a}$ & $47,53 \mathrm{a}$ & $(-)$ \\
\hline \multirow{4}{*}{28} & Kontrol & 50,43 & 52,35 & $51,39 \mathrm{ab}$ \\
\hline & 5 & 53,83 & 59,09 & $56,46 a$ \\
\hline & 10 & 44,61 & 47,50 & $46,05 \mathrm{~b}$ \\
\hline & Rerata & $49,62 \mathrm{a}$ & $52,98 \mathrm{a}$ & $(-)$ \\
\hline \multirow{4}{*}{35} & Kontrol & 60,79 & 56,66 & $58,72 \mathrm{a}$ \\
\hline & 5 & 60,22 & 69,20 & $64,71 \mathrm{a}$ \\
\hline & 10 & 48,65 & 58,84 & $53,74 \mathrm{a}$ \\
\hline & Rerata & $56,55 \mathrm{a}$ & $61,57 \mathrm{a}$ & $(-)$ \\
\hline \multirow{4}{*}{42} & Kontrol & 63,59 & 68,90 & $66,24 a$ \\
\hline & 5 & 64,93 & 75,65 & $70,29 a$ \\
\hline & 10 & 53,03 & 88,36 & $70,70 \mathrm{a}$ \\
\hline & Rerata & $60,52 b$ & $77,64 a$ & $(-)$ \\
\hline \multirow{4}{*}{49} & Kontrol & 69,89 & 74,25 & $72,07 a$ \\
\hline & 5 & 69,79 & 81,05 & $75,42 \mathrm{a}$ \\
\hline & 10 & 58,24 & 95,24 & $76,74 a$ \\
\hline & Rerata & $65,97 b$ & $83,52 \mathrm{a}$ & $(-)$ \\
\hline \multirow{4}{*}{56} & Kontrol & 86,27 & 98,30 & $92,29 a$ \\
\hline & 5 & 87,08 & 100,16 & $93,62 \mathrm{a}$ \\
\hline & 10 & 73,94 & 122,04 & $97,99 \mathrm{a}$ \\
\hline & Rerata & $82,43 b$ & $106,83 \mathrm{a}$ & $(-)$ \\
\hline \multirow{4}{*}{63} & Kontrol & 114,73 & 119,20 & $116,96 a$ \\
\hline & 5 & 111,65 & 131,91 & $121,78 \mathrm{a}$ \\
\hline & 10 & 95,48 & 151,57 & $123,53 \mathrm{a}$ \\
\hline & Rerata & $107,29 b$ & $134,23 a$ & $(-)$ \\
\hline
\end{tabular}

Keterangan: Angka pada baris dan kolom diikuti huruf yang sama menunjukan beda pada tingkat nyata $(\alpha)=5 \%$ menurut uji DMRT (-) tidak terjadi interaksi antar faktor.

\section{Jumlah Daun}

Hasil sidik ragam (Anova) menunjukan tidak terjadi interaksi antar perlakuan takaran kompos biochar dan diameter ahukle'an terhadap jumlah daun pada waktu pengamatan 21 HST, 28 HST, 35 HST dan 56 HST. Sedangkan hasil sidik ragam (Anova) menunjukan terjadi interaksi antara perlakuan takaran kompos biochar dan diameter ahukle'an secara positif $(\mathrm{P}<0.05)$ terhadap jumlah daun pada waktu pengamatan 42 HST, 49 HST dan 63 HST dan Aras perlakuan takaran kompos biochar $10 \mathrm{t} / \mathrm{Ha}$ menunjukkan berbeda nyata terhadap jumlah daun $5 \mathrm{t} / \mathrm{Ha}$ pada waktu pengamatan. Perlakuan takaran kompos biochar $10 \mathrm{t} / \mathrm{Ha}\left(\mathrm{B}_{2}\right)$ gram dan diameter ahukle'an $15 \mathrm{~cm}$ cenderung meningkatkan jumlah daun (Tabel 4)

\section{Luas Daun}

Hasil sidik ragam (Anova) menunjukan tidak terjadi interaksi antar perlakuan takaran kompos biochar dan diameter ahukle 'an terhadap luas daun. Aras perlakuan takaran kompos biochar $0 \mathrm{t} / \mathrm{Ha}$ (kontrol) dan diameter ahukle'an 7,5 menghasilkan luas daun paling banyak yang menunjukkan tidak berbeda nyata terhadap luas daun (Tabel 5)

\section{Berat pipilan Kering Per Tanaman}

Hasil sidik ragam (Anova) menunjukan tidak terjadi interaksi antar perlakuan takaran kompos biochar dan diameter ahukle an terhadap berat pipilan kering per tanaman. Aras perlakuan takaran kompos biochar dan diameter ahukle'an menunjukkan tidak berbeda nyata terhadap berat pipilan kering per tanaman (Tabel 6)

\section{Berat kering berangkasan}

Hasil sidik ragam (Anova) menunjukan tidak terjadi interaksi antar perlakuan takaran kompos biochar dan diameter ahukle'an terhadap kering berangkasan. Aras perlakuan takaran kompos biochar dan diameter ahukle'an menunjukkan tidak berbeda nyata terhadap berat kering berangkasan (Tabel 7) 
Tabel 4. Jumlah Daun (helai)

\begin{tabular}{|c|c|c|c|c|}
\hline \multirow{2}{*}{$\begin{array}{c}\text { Waktu Pengamatan } \\
\text { (HST) }\end{array}$} & \multirow{2}{*}{$\begin{array}{c}\text { Takaran Kompos } \\
\text { Biochar }(\mathrm{t} / \mathrm{Ha})\end{array}$} & \multicolumn{2}{|c|}{ Diameter ahukle'an $(\mathrm{cm})$} & \multirow{2}{*}{ Rerata } \\
\hline & & 7,5 & 15 & \\
\hline \multirow{4}{*}{21} & Kontrol & 4,33 & 4,33 & $4,33 a$ \\
\hline & 5 & 4,22 & 3,89 & $4,05 \mathrm{a}$ \\
\hline & 10 & 3,77 & 5,11 & $4,44 \mathrm{a}$ \\
\hline & Rerata & $4,11 \mathrm{a}$ & $4,44 a$ & $(-)$ \\
\hline \multirow{4}{*}{28} & Kontrol & 5,22 & 5,67 & $5,44 \mathrm{a}$ \\
\hline & 5 & 5,33 & 5,33 & $5,33 \mathrm{a}$ \\
\hline & 10 & 4,88 & 6,20 & $5,54 \mathrm{a}$ \\
\hline & Rerata & $5,14 \mathrm{a}$ & $5,73 a$ & $(-)$ \\
\hline \multirow{4}{*}{35} & Kontrol & 6,55 & 6,44 & $6,50 \mathrm{a}$ \\
\hline & 5 & 6,33 & 6,55 & $6,44 a$ \\
\hline & 10 & 5,66 & 7,47 & $6,57 \mathrm{a}$ \\
\hline & Rerata & $6,18 \mathrm{a}$ & $6.82 \mathrm{a}$ & $(-)$ \\
\hline \multirow{4}{*}{42} & Kontrol & $7,67 \mathrm{ab}$ & $7,89 \mathrm{ab}$ & 7,78 \\
\hline & 5 & $7,11 \mathrm{ab}$ & $7,44 \mathrm{~b}$ & 7,27 \\
\hline & 10 & $6,89 \mathrm{~b}$ & $9,11 \mathrm{a}$ & 8,00 \\
\hline & Rerata & 7,22 & 8,14 & $(+)$ \\
\hline \multirow{4}{*}{49} & Kontrol & $9,33 \mathrm{~b}$ & $9,22 \mathrm{~b}$ & 9,28 \\
\hline & 5 & $8,89 \mathrm{~b}$ & $8,67 \mathrm{~b}$ & 8,78 \\
\hline & 10 & $7,88 \mathrm{~b}$ & $11,22 \mathrm{a}$ & 9,55 \\
\hline & Rerata & 8,70 & 9,70 & $(+)$ \\
\hline \multirow{4}{*}{56} & Kontrol & 11,22 & 11,22 & $11,22 \mathrm{a}$ \\
\hline & 5 & 10,78 & 11,44 & $11,11 \mathrm{a}$ \\
\hline & 10 & 9,89 & 14,21 & $12,05 \mathrm{a}$ \\
\hline & Rerata & $10,63 \mathrm{a}$ & $12,29 \mathrm{a}$ & $(-)$ \\
\hline \multirow{4}{*}{63} & Kontrol & $12,77 \mathrm{ab}$ & $13,11 \mathrm{ab}$ & 12,94 \\
\hline & 5 & $12,88 \mathrm{ab}$ & $12,66 a b$ & 12,77 \\
\hline & 10 & $10,78 \mathrm{~b}$ & $16,16 \mathrm{a}$ & 13,47 \\
\hline & Rerata & 12,14 & 13,98 & $(+)$ \\
\hline
\end{tabular}

Keterangan : Angka pada baris dan kolomdiikutihuruf yang samamenunjukanbeda pada tingkatnyata $(\alpha) 5 \%$ menurut uji DMRT, (-) tidak terjadi interaksiantarfaktor, (+) terjadiinteraksiantarfaktor.

Tabel 5. Luas Daun $\left(\mathrm{cm}^{2}\right)$

\begin{tabular}{cccc}
\hline Takaran Kompos & \multicolumn{2}{c}{ Diameter ahukle'an $(\mathrm{cm})$} & \multirow{2}{*}{ Rerata } \\
\cline { 2 - 3 } Biochar (t/Ha) & 7,5 & 15 & \\
\hline Kontrol & 450,40 & 352,86 & $401,63 \mathrm{a}$ \\
5 & 341,50 & 247,44 & $294,47 \mathrm{a}$ \\
10 & 273,55 & 284,95 & $279,25 \mathrm{a}$ \\
\hline Rerata & $355,15 \mathrm{a}$ & $295,08 \mathrm{a}$ & $(-)$
\end{tabular}

Keterangan: Angka pada baris dan kolom diikuti huruf yang sama menunjukan beda pada tingkat nyata $(\alpha)=5 \%$ menurut uji DMRT (-) tidak terjadi interaksi antar faktor.

Tabel 6. Berat Pipilan Kering Pertanaman (g)

\begin{tabular}{cccc}
\hline Takaran Kompos & \multicolumn{2}{c}{ Diameter ahukle'an $(\mathrm{cm})$} & \multirow{2}{*}{ Rerata } \\
\cline { 2 - 3 } Biochar $(\mathrm{t} / \mathrm{Ha})$ & 7,5 & 15 & $22,58 \mathrm{a}$ \\
\hline Kontrol & 20,89 & 24,26 & $44,68 \mathrm{a}$ \\
5 & 33,57 & 55,78 & $15,26 \mathrm{a}$ \\
\hline 10 & 15,14 & 15,38 & $(-)$
\end{tabular}

Keterangan: Angka pada baris dan kolom diikuti huruf yang sama menunjukan beda pada tingkat nyata $(\alpha)=5 \%$ menurut uji DMRT (-) tidak terjadi interaksi antar faktor.

Tabel 7. Berat Kering Berangkasan (t/ha)

\begin{tabular}{cccc}
\hline Takaran Kompos & \multicolumn{2}{c}{ Diameter ahukle'an $(\mathrm{cm})$} & \multirow{2}{*}{ Rerata } \\
\cline { 2 - 3 } Biochar $(\mathrm{t} / \mathrm{Ha})$ & 7,5 & 15 & $13,30 \mathrm{a}$ \\
\hline Kontrol & 12,83 & 13,76 & $10,50 \mathrm{a}$ \\
5 & 9,12 & 11,87 & $14,30 \mathrm{a}$ \\
\hline 10 & 13,64 & 14,96 & $(-)$ \\
\hline Rerata & $11,86 \mathrm{a}$ & $13,53 \mathrm{a}$ &
\end{tabular}

Keterangan: Angka pada baris dan kolom diikuti huruf yang sama menunjukan beda pada tingkat nyata $(\alpha)=5 \%$ menurut uji DMRT (-) tidak terjadi interaksi antar faktor.

\section{Indeks panen}

Hasil sidik ragam (Anova) menunjukan tidak terjadi interaksi antar perlakuan takaran kompos biochar dan diameter ahukle'an terhadap indeks panen. Aras perlakuan takaran kompos biochar dan diameter ahukle'an menunjukkan tidak berbeda nyata terhadap indeks panen (Tabel 8).

Tabel 8. Indeks Panen (\%)

\begin{tabular}{cccc}
\hline Takaran Kompos & \multicolumn{2}{c}{ Diameter ahukle'an $(\mathrm{cm})$} & \multirow{2}{*}{ Rerata } \\
\cline { 2 - 3 } Biochar $(\mathrm{t} / \mathrm{Ha})$ & 7,5 & 15 & \\
\hline Kontrol & 81,69 & 68,73 & $75,21 \mathrm{a}$ \\
5 & 82,14 & 91,02 & $86,58 \mathrm{a}$ \\
10 & 72,83 & 75,48 & $74,16 \mathrm{a}$ \\
\hline Rerata & $78,89 \mathrm{a}$ & $78,41 \mathrm{a}$ & $(-)$ \\
\hline
\end{tabular}

Keterangan: Angka pada baris dan kolom diikuti huruf yang sama menunjukan beda pada tingkat nyata $(\alpha)=5 \%$ menurut uji DMRT (-) tidak terjadi interaksi antar faktor.

\subsection{Pembahasan}

Ruang pori-pori tanah terbentuk dari partikel tanah dipengaruhi oleh tekanan. Sedangkan konsistensi tanah tergantung pada stabilitas ukuran ruang tanah. Sirkulasi yang berlangsung didalam tanah dipengaruhi oleh kerapatan porositas. Pertukaran oksigen dan karbon dioksida didalam tanah dipengaruhi oleh faktor air dan udara didalam satuan volume tanah (Saadat et al, 2017). Pori-pori tanah yang mengandung air disebut juga dengan kadar lengas tanah. Kebutuhan air pada setiap tanaman berbeda-beda tergantung dari jenis tanaman. Kadar lengas tanah sangat penting dalam pertanian karena pengaturan lengas tanah dapat diatur untuk serapan unsur hara dan pernafasan akar-akar tanaman (Suharto, 2013). Ukuran butiran tanah sangat berpengaruh terhadap sifat tanah. Sifat kelekatan tanah dapat terjadi jika kadar air didalam tanah rendah. Konsistensi basah pada air disekitar kapasasitas lapangan digunakan untuk menilai derajat kelekatan tanah terhadap benda-benda yang menempelinya.

Kadar lengas tanah adalah sejumlah air yang ditahan pada ruang antara partikel pada tanah yang ditunjukkan oleh kelembaban pada permukaan tanah yang digunakan sebagai indikator kekeringan (Hadi, 2012). Kadar lengas tanah dapat menentukan proses penyerapan hara dan pernapasan akar-akar tanaman di atasnya. Tanah dapat dikatakan baik apabila tanah tersebut memiliki kandungan air yang cukup serta mengandung bahan-bahan organik di dalamnya. Semakin baik kualitas tanah maka semakin baik pula pertumbuhan dan perkembangan suatu tanaman. Menurut Prijono \& Laksmana (2016) kedalaman profil tanah mempengaruhi kadar lengas pada tanah. Lapisan tanah yang berada di bagian bawah cenderung memiliki tingkat kadar lengas yang lebih rendah dibandingkan dengan lapisan di atasnya.

Ketersediaan air didalam tanah, merupakan faktor pembatas utama baik terhadap penyebaran tumbuhan dipermukaan bumi maupun terhadap kuantitas produksi pertanian. Jumlah ketersediaan air yang bagi daerah agak kering ditentukan besarnya curah hujan efektif, sangat menentukan besarnya produksi pertanian di daerah itu. Tanaman jagung yang dikenal mempunyai daya adaptasi tinggi dibandingankan dengan tanaman serealia lain, produksinya pun sangat dibatasi oleh ketersediaan air didalam tanah (Suryatna Effendi, 1977) Hampir setiap proses yang terjadi didalam tubuh tanaman, langsung atau tidak sangat dipengaruhi oleh ketersediaan air. kelakuan dan ketersediaan unsur hara dalam tanah juga dipengaruhi oleh kadar air (lengas) dalam tanah (Black, 1968). Kekurangan air selama waktu yang lama pada fase pertumbuhan akan menurunkan hasil, karena beberapa proses didalam tubuh tanaman, misalnya pembentukan karbohidrat, hidratasi protoplas dan pengangkutan makanan serta mineral menjadi lambat, akibatnya pertumbuhan tanaman juga terhambat (Hilliel, 1971).

\section{Simpulan}

Berdasarkan hasil penelitian dapat disimpulkan bahwa terjadi interaksi antar perlakuan kompos biochar dan diameter ahukle'an terhadap parameter pengamatan suhu tanah $28 \mathrm{HST}, 35 \mathrm{HST}, 42 \mathrm{HST}, 56 \mathrm{HST}$, dan $63 \mathrm{HST}$; jumlah daun $42 \mathrm{HST}$, $49 \mathrm{HST}$, dan 63 HST. Perlakuan diameter ahukle'an 15 $\mathrm{cm}$ berpengaruh terhadap hasil berat pipilan kering per tanaman $(44,68 \mathrm{~g})$. Takaran kompos biochar $5 \mathrm{t} / \mathrm{Ha}$ berpengaruh nyata terhadap hasil berat pipilan kering per tanaman $(31,81 \mathrm{~g})$.

\section{Pustaka}

Black, C. A. 1968. Soil Plants Relationships Wiley Eas Tern Private Limited. New Delhi. India.

Chan, K,Y., van Zwieten, I. Meszaros, A. Downie, and S. Joseph. 2007. Agronomic values of greenwaste biochar as a soil amendment. Australia Journal of soil Research, 45, 629-634.

Hadi, A.P. 2012. Penentuan Tingkat Kekeringan Lahan Berbasis Analisa Citra Aster Dan Sistem Informasi Geografis. Geografi Indonesia, 26(1): 1-26.

Gomez K A dan Gomez A A. 1995. Prosedur Statistik Untuk Penelitian Pertanian. Edisi

ke 2. UI Press: Jakarta

Hilliel, D., 1971. Soil and water. First ed Academic Press Inc, New York.

Leki Seran Y. B. Moerdolelono B. De Rosari dan Julistia Bobohoe . 2002. Prosepek Pengembangan Agribisnis Jagung di Kawasan Besikama Belu. Proseding Siminar Regional Kawasan Timur Indonesia. Peningkatan kinerja BPTP dan komunikasi hasil-hasil Penelitian dalam mendukung Pembangunan Pertanian di Nusa Tenggara dan Sosialisasi Program Kapet Mbay tingkat Provinsi NTT, Kerja sama Balai Pengkajian Teknologi Pertanian NTT dengan BP - KAPTE Mbay dan Balitbangda Provinsi NTT.

Melo, L.C.A., Coscione, A.R., Abreu, C.A., Puga, A. P. and Camargo, O.A. 2013. Influence of pyrolysis temperature on cadmium and zinc sorption capacity of sugar cane straw-derived biochar.Bio Resources8 (4), 4992 5004

Murdolelono, B., D.F. Fahik, J. Babihoe dan A.Bamualim. 1999. Ahukle'an, Teknologi Indigenous Budidaya Jagung di Kawasan Besikama. Prosiding Lokakarya Regional Penerapan Teknologi Indigenous dan Teknologi Maju Menunjang Pembangunan Pertanian di Nusa Tenggara. Kupang, 1-2 Maret 1999. J Nulik, Wirdahayati RB, EO Momuat, Djiman Sitepu Endrizal dan J Bobihoe (Penyunting). 80 - 83. Badan Litbang Pertanian.

Nurida, N.L., 2012. Biochar SP 50. Balai Penelitian Tanah.Badan Peneliti dan Pengembangan Pertanian. Kampus Peneliti Pertanian. Cimanggu. 
Prijono, S dan Laksmana, M.T.S. 2016. Studi Laju Transpirasi Peltophorum dassyrachis dan Gliricidia sepium Pada Sistem Budidaya Tanaman Pagar Serta Pengaruhnya Terhadap Konduktivitas Hidrolik Tidak Jenuh. Jurnal PAL, 7(1): 2087-3522.

Saadat, S., K. K. Seed, S. Mehdi, G. Manoochehr, and Z. Mehdi. 2014. Effect of Soil Pore Size Distribution on Plant Avaiable Water and Least Limiting Water Range as Soil Physical Quality Indicators, 32(13): 321 343.

Suharto, E., 2013. Kapasitas Simpanan Air Tanah pada Sistem Tata Guna Lahan LPP Tahura Raja Lelo Bengkulu, 8(1): 44-49.

Suryatna Effendi, 1977. Bercocok tanam jagung Edisi ke .C.V. Jasaguna Jakarta.

Wariso. 2000. Kumpulan artikel Sosiologi untuk Peneliti Penyuluh Pertanian (KASPE) PT Cakra Hasta Konsultan. Nusa Tenggara Agricultural Area Development Project. Balai Pengkajian Teknologi 